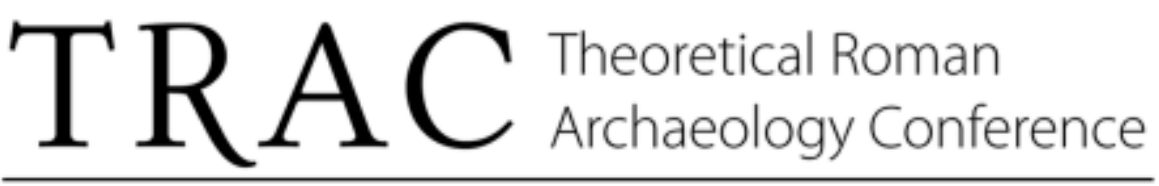 \\ www.trac.org.uk
}

\section{Paper Information:}

Title: Craft and Social Identity of Metalworkers in Ptolemaic and Roman Egypt

Author: Mark Eccleston

Pages: $1-16$

DOI: http://doi.org/10.16995/TRAC2006 116

Publication Date: 29 March 2007

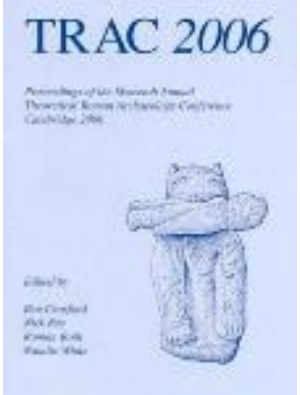

\section{Volume Information:}

Croxford, B., Ray, N., Roth, R., and White, N. (eds) 2007. TRAC 2006: Proceedings of the Sixteenth Annual Theoretical Roman Archaeology Conference, Cambridge 2006. Oxford: Oxbow Books.

\section{Copyright and Hardcopy Editions:}

The following paper was originally published in print format by Oxbow Books for TRAC. Hard copy editions of this volume may still be available, and can be purchased direct from Oxbow at http://www.oxbowbooks.com.

TRAC has now made this paper available as Open Access through an agreement with the publisher. Copyright remains with TRAC and the individual author(s), and all use or quotation of this paper and/or its contents must be acknowledged. This paper was released in digital Open Access format in April 2013. 


\title{
Craft and Social Identity of Metalworkers in Ptolemaic and Roman Egypt
}

\author{
Mark Eccleston
}

\section{Introduction}

Mastery of the mass-production of objects made from iron and copper alloys was a valuable part of the urban and rural Roman economy and a significant factor in military campaigns waged by the imperial armies (Manning 1987; Sim and Ridge 2002). It is rather surprising, therefore, given the importance of the metalworking industry throughout the Roman world, that it is an area not at all well studied or understood. This paper will discuss some of the evidence for the metalworking industries in Egypt via a brief examination of a selection of the texts in Greek that are extant, coupled with a discussion of new evidence for blacksmithing in Roman Egypt that formed part of my Ph.D. research (Eccleston 2002; Eccleston 2006).

Archaeological and textual evidence from Egypt is sometimes seen as anomalous when attempting to use it to infer practices elsewhere in the Hellenistic and Roman worlds, even elsewhere in the Eastern Mediterranean where Greek was also the administrative language of choice. Papyrologists working on Egyptian material such as Bagnall (1995: 11-13) see this as less problematic since finds of documents at sites such as Vindolanda, Petra, and Dura Europa have been more fully studied. Until relatively recently there has been a tendency for disciplines that can be broadly defined as 'historical archaeology', which can include all periods of Egyptian history after the predynastic, to privilege the importance of the extant textual evidence over the archaeological evidence (Andrén 1998: 41-43; Moreland 2001: 98; Trigger 1989: 40). In the case of all periods of Egyptian history, there can be no doubt that the evidence from texts is absolutely fundamental to forming our current understandings of many aspects of Egyptian society. However, when using texts from any period, or any context, one must exercise a certain amount of caution in interpreting or assigning them meaning. The specific context in which any texts were found (if known), and the social and political status of the writer and subject(s) of the text (if known), which by inference will have had an influence on the purpose or agenda of the writer, must be taken into account. This is also the case when assessing the use of texts by scholars, as they will also have some kind of bias when interpreting the significance and meaning of texts. Moreland (2001: 87-97) argues that texts, from all periods, are just one material manifestation of the evidence for one group of people exercising control over another. Bagnall (1995: 13) makes the same point for the Egyptian material by saying that 'a very large part (although hardly all) of what was written existed in some sense to exercise someone's power over someone else.' In Egypt, the largest consumer and user of papyrus were the government or its agents. There were also a large number of private persons using papyrus to record ownership of various commodities, obligations, evidence of the discharge of obligations, and private letters (Bagnall 1995: 14).

In European historical archaeology there has recently been a certain amount of self-reflective analysis about the way that in the past, scholars have relied upon certitude in the evidence from the extant texts, and not engaged thoroughly with other types of material evidence or with 
archaeological theory (Moreland 2001: 98). This has been seen by Johnson (1999: 33) as part of the 'relentless conservatism' of the discipline, and the unwillingness of some within the discipline to engage with new ideas or other types of primary source materials. In specific relation to British medieval and post-medieval archaeology, Moreland (2001: 83) has suggested the need for a similar methodology to that of Hodder's 'contextual archaeology', whereby one uses all of the available archaeological evidence, rather than using only objects or texts. This methodology is hardly revolutionary or unused by others within Egyptian archaeology; however, there remains a need for a greater engagement with such ideas.

Identity in the Roman world has been an issue that has received much attention, especially amongst those working in the Western Empire. Identity is often used to discuss matters of cultural identity, as can be seen in various papers in recent volumes such as Laurence and Berry (1998), to give just one example. In this sense, scholars are often interested in how people originally from areas conquered by Rome become 'Roman', or continue to express aspects of their 'native culture'. Whilst this is a topic of considerable interest, particularly to British academics, there are other areas of 'identity' that can also prove to be useful when attempting to understand other aspects of the Roman world. In a recent study, Mattingly (2004) provides an excellent summary of the current state of research on the topic using evidence from Roman Britain to illustrate his point.

In Egypt during the Ptolemaic and Roman Periods, the concept of identity can be quite complex, especially when using different types of evidence to attempt to infer how people were identified within different social, political and economic contexts. It was not uncommon for people to have a partly 'Egyptian' identity for religious or funerary purposes, and a Hellenistic or Roman identity for the purposes of political, economic or general social advancement (Quaegebeur 1992). It is not my intention in this paper to delve into the deep complexity of this topic, rather to highlight this as an area that is already well-addressed within certain literature (see Johnson 1992 for an edited collection of papers which address aspects of this well). In the context of this paper I am most interested in Mattingly's (2004: 10-11) category of 'employment', and more specifically, what it meant to be identified in texts as belonging to one of the metalworking professions in Ptolemaic and Roman Egypt.

Another theoretical construct that can also usefully be applied to the study of industry is Leroi-Gourhan's $(1943 ; 1945 ; 1964 a ; 1964 b ; 1965)$ concept of the chaine opératoire. In its simplest form, chaîne opératoire can be seen purely as the 'operational sequence' of actions by which an object is made, and this is often how it is used (see Buchez 2004 for a recent example using data from Egyptian ceramics). This part of chaîne opératoire research is concerned with reconstructing the technical sequences required to produce an object. These processes can be deduced by the careful study of the distribution of industrial by-products in certain archaeological contexts, as well as their scientific analysis. However, to limit a study to this alone is to miss the key point of the concept, whereby all factors related to the manufacture of the object must be considered before one can even begin to understand how and why objects are made. As Dobres (1999: 125) describes, this type of analysis is also used to 'infer something of the abstract cognitive processes and underlying normative logic systems structuring' everyday and technical acts. In other words, in addition to simply recording and reconstructing physical characteristics of the material remains, one should also consider the economic factors relating to their production and distribution, social relations between artisans and other members of society, and the symbolic nature of the objects. When these concepts have been used most effectively by archaeologists to address questions concerning technology, they have generally been applied to the study of lithic technology (e.g. Edmonds 1990; Dobres 2000); the particular technology that 
most of the French exponents of chaîne opératoire theory were themselves most interested in studying (Audouze 2002: 286-287). The concept of the chaine opératoire is not something that should be considered purely as an abstract concept only applicable to studies of lithic industries in prehistory. This has been demonstrated by the various examples used by Lemonnier (1992) that include arrow technology from New Guinea (51-56), and aeroplane design (66-77). The archaeological data set available for Ptolemaic and Roman Egypt lends itself particularly well to addressing this kind of research question due to the large amount of material remains and texts. The presence of texts is especially useful in elucidating areas that would otherwise be invisible in the archaeological record, and thus allowing conclusions to be drawn on wider ranging aspects of the chaine opératoire, such as social and political organisation and gender relations.

The unique preservation of archaeological finds in Egypt, due to the dry climate, has provided archaeologists and ancient historians with a wealth of primary data that includes both artefacts and texts. Given the richness of this set of primary source material, Ptolemaic and Roman Egypt seems to be an ideal setting to attempt to place these concerns clearly within an archaeological context that has not often been the domain of theoretical engagement. I concur with Dobres and Robb (2000: 14) when they say that archaeologists should take the lead in developing their own theoretical paradigms for discussing areas such as material culture. This is particularly the case with material culture studies in Egypt, where the amount of evidence is so vast and its preservation so remarkable. There is a clear need to learn from the theoretical discussions taking place more generally in archaeology, and to apply such useful paradigms explicitly to the study of Egyptian material culture.

\section{Evidence for Metalworking Professions in Ptolemaic and Roman Egypt}

This section will provide a brief summary of some of the textual and archaeological evidence for metalworking in Egypt during the Ptolemaic and Roman Periods. It is not possible to discuss every extant text in detail in the context of this paper. However, an overview of the range of texts will be given along with a discussion of some specific texts. I plan to publish a more detailed discussion of the complete corpus of texts elsewhere in the near future. Similarly, the discussion of the archaeological evidence only serves to highlight the lack of published evidence for the metalworking industry in Ptolemaic and Roman Period Egypt. Hopefully, this kind of evidence will begin to appear in future excavation reports now that more rigorous excavation and recording methodologies have been adopted throughout Egypt.

Texts from this period in Egypt have come from a variety of sources, some of which are more dubious than others. Excavation of Ptolemaic and Roman Period sites invariably yield texts in one form or another, be it on papyrus, ceramic, bone, or clay and so on. In the following discussion I follow Bagnall (1995: 9-10), and class all such documents as 'papyrus' or 'papyri'. The actual find context of many texts is unknown, especially for those recovered before the adoption of more rigorous methods of recording in Egyptian field archaeology, and those purchased on the antiquities market. The system of identifying specific texts is based on the widely used and accepted method laid out in the Checklist of Editions of Greek and Latin Papyri, Ostraca and Tablets: Fifth Edition (Oates et al. 2001; http://scriptorium.lib.duke.edu /papyrus/ texts/clist.html). This method uses an abbreviation of the site, archive, or library where the documents were either found or are now housed, prefixed by a ' $\mathrm{P}$ ' for documents written on papyrus, and an ' $\mathrm{O}$ ' for ostraka. One of the most well known collections of papyri, from the site 
of Oxyrhynchus, is therefore designated P.Oxy. Specific texts are then referred to by a specific sequential numbering system that is possibly followed by a line number within that text.

Textual evidence for metalworking in Egypt comes primarily in the form of documentary papyri written in Greek. The papyrological record relating to metalworking is the richest of all the high-temperature industries, although it has yet to be utilised by archaeologists interested in the industry. The metalworking papyri span approximately 1000 years of Egyptian history, with texts in Greek existing from the Ptolemaic Period through to the time around the Arab conquest of Egypt. Whilst it is extremely difficult to make broad conclusions using material of such a large chronological range, some of the information in the texts is useful for understanding how the industry worked at specific times in Egypt's history. Although most of the texts are written primarily in Greek, some have small sections or signatures in Demotic and Latin, and in the much later texts, some notations are in Arabic. These are rare, however, and the majority of them are entirely in Greek.

There are many words in Greek that relate to different specialist metalworking professions, far more than for the pottery industry, for example. In the only major detailed study of industries in Ptolemaic and Roman Egypt to date, Reil (1913: 59-64) lists the known terminology for the different metalworking specialties in the Greek papyri in Egypt. Although the work is now over 90 years old, the list of professions he gives is still a useful starting point, and I am not aware of any new words that are not contained in Reil's list. These are, in Greek alphabetic order:

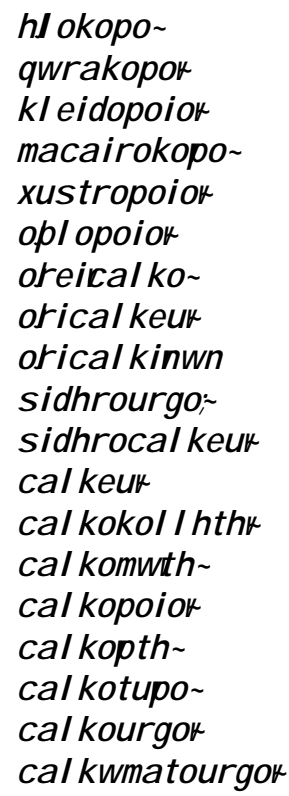

\author{
nail smith \\ maker of breastplates \\ locksmith \\ maker of cutlery/knives \\ scythe maker, lance maker \\ maker of armour, armourer \\ brass smith \\ brass smith \\ brass smith \\ smith, blacksmith. \\ smith, blacksmith \\ smith, bronze smith \\ copper welder, copper smith \\ copper smith \\ bronze worker, smith, maker of bronze \\ copper smelter \\ smith \\ worker in bronze \\ maker of bronze plates
}

Of the terms noted by Reil (1913: 59-64), those most commonly occurring in the papyri are sidhrourgor (blacksmith), sidhrocal keu $\forall$ (blacksmith), calkeu $*$ (bronzesmith or blacksmith), and hJ okopo (nailsmith). As this study is not an attempt to provide a complete corpus and in-depth analysis of all of the known terminology, only some of the texts relating to the four most common professions will be discussed. The breakdown of the most common words occurring in the papyri is as follows: 


\section{cal keur sidhrourgor sidhrocal keu hJ okopo}

(bronzesmith or blacksmith)

(blacksmith)

(blacksmith)

(nailsmith)
47 published references

14 published references

5 published references

11 published references

Whilst more than half are simply lists of names for the purposes of taxation or census collecting and impart no useful information that relates directly to metalworking practices, they are useful in that they show that at a particular place and time, there was a person who was identified primarily by their metalworking profession. These texts can be used to provide a broad context for a discussion of the metalworking industry in general and allow the agents who performed the actions of the craft to become even more visible. Other texts provide more detailed information about the various roles of specific metalworking professions at different times and places.

It is not known to what degree people who were identified by a specific professional title worked on other types of material or objects. This will probably never be known due to the problems of correlating people known from texts to specific archaeological contexts that have evidence for metalworking. The roots of the first three words for a blacksmith clearly derive

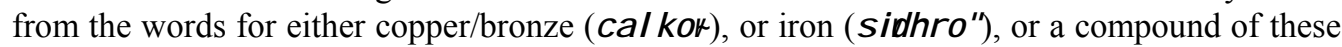
words. By the Roman Period, c a I k o $\forall$ could also be used to mean iron or metal in general, and words for the specific professions are similarly interchangeable between specialists in different metals. It may have been the case that, in the first instance, a c a I k e u $\forall$ worked solely with bronze, as iron was not in common use at the time of the first attestation of the word. Once iron came into more common usage, the terms sidhrourgor (blacksmith), and sidhrocal keu (blacksmith) could have been introduced to differentiate between specialists, as the skills needed to work with iron and bronze are different.

One Ptolemaic Period text that implies that there was a clear differentiation between the jobs undertaken by people identified with such professional titles is UPZ 182, a text of the late second century B.C.E., where both a s i dh r o u r gor (blacksmith) and c a I k e u $\forall$ (blacksmith) are listed. One must assume that the scribe differentiated between these two people for some specific administrative purpose, however, the exact reason for this is not clear from the extant text. It has been suggested by Latjar (1991: 57) on the basis of one text, P.Oxy 84, that there is some possible differentiation that might be made between a s idh r o u r go r and a s idh r o c a I keu $\forall$. An extrapolation of his general hypothesis is that a $\mathrm{s}$ idh r ou r gor was responsible for collecting and smelting the ore into bloom iron, and that a s idhroc a l keu $\forall$ was what one might describe as a 'bloom-smith', i.e. someone who later worked the smelted bloom of iron into solid ingots, bars or billets. The manufacture of objects was then the realm of other specialist craftsmen with more specific titles, such as those listed above. This contention might be true, but it is based on very tenuous evidence from one text, and it does not take into account the far more common title of c a I keu $\forall$ (bronzesmith or blacksmith) and what their function may have been. It is clear that more work needs to be done on this topic before a more definitive solution can be provided.

An important dossier of taxation documents from Philadelphia, located in the east of the Fayum, dating to c. 20-40 C.E. during the reign of Tiberius (Johnson and van Hoesen 1931), mentions several different blacksmiths, all of which are described as c a I ke u $\forall$ (bronzesmith or blacksmith). P.Princ 14 mentions two different blacksmiths in the one register of taxes, namely Petermothis (P.Princ 14.Col I.21) and Herakles (P.Princ Col II.21). The existence of Herakles, the blacksmith at Philadelphia, is attested in another taxation list from the site (SB 11481.25) that 
provides a similar, but slightly different list to that of P.Princ 14. There is no doubt that this is the same person as both are identified as Herakles, son of Herakles and are of a similar date. Other texts from the same archive also mention different smiths again, implying that there were several smiths at Philadelphia within a relatively short time period, with some operating simultaneously. P.Princ 13 Col V.39 lists Herieus the blacksmith, and P.Princ 2 Col VI.23 the partial name of a blacksmith who is called '(likewise) Pe..teus the younger, blacksmith' (P e..te u (o mo i w ) ne (w te r $0 \sim)$ c a I k (e u $\forall)$ ). P.Corn 21, also a register of tax-payers from Philadelphia dated to 23 C.E., mentions another two blacksmiths from the city, in this case Apamous (P.Corn 21.159), and Musthas (P.Corn 21.345). Given the relative size of the site, it should not be a surprise that multiple smiths were working there simultaneously.

In terms of craft identity, it is possible to suggest with a high degree of certainty that the people that are specifically identified as blacksmiths for the purposes of tax collection and census documents, were primarily identified this way where they were living. They probably worked as full-time specialists in the profession, or at least obtained most of their income in this manner. The actual social status or standing of the people involved is harder to determine as it is very difficult to match many of the people mentioned to specific professions. The level of tax being paid could also vary based on circumstance. A more detailed study of tax registers would need to be undertaken to take this further.

An interesting dossier of taxation documents that all relate to a blacksmith are the thirteen ostraka now in Leiden and Chicago, which pertain to the payment of a certain type of tax (dhmosi ) by a blacksmith (sidhrourgor) named Patermouthis during the seventh/eighth century C.E. with a terminus ante quem of 725 C.E. (Hickey and Worp 1997). Although the date of these texts is quite late, they are still useful in understanding the organisation of the industry at an earlier date due to the long continuation of certain laws and practices (Hakim 2001). The type of tax being levied, the dhmosi $\mathbf{g}$, is normally associated with a land tax, although given the small size of the payments, Hickey and Worp (1997: 84-86) suggest that in this case they may have been partially, or completely, trade taxes, rather than land taxes. They go on to suggest that these were possibly paid to the treasurer of a corporation or guild ( $k$ ef a $\mathbf{V}$ a i w th $\boldsymbol{}$ ), of which Patermouthis was a member (ibid). It is significant that at this time there is still a guild of smiths functioning in the vicinity of Patermouthis' home, wherever that was. This is a problematic point with a lot of texts of this type as they were purchased on the antiquities market in the late nineteenth and early twentieth centuries, and like this group of ostraka, have no provenance apart from the editors speculating on possibly Upper Egypt (Hickey and Worp 1997: 82-83).

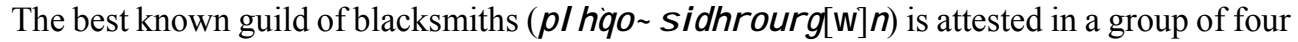
proskynema inscriptions at Deir el-Bahri dating to the fourth century C.E. (Latjar 1991). Even though the text is poorly preserved, and no specific details on the profession are offered, it is still possible to glean some information about blacksmiths. The word used in the text for the corporation or guild ( $\left.p \mid h q_{0} \sim\right)$, and the ritual acts described as being performed by the men suggest that the guild had a long history, possibly back into the Early Roman or Ptolemaic Period (Latjar 1991: 65). The first inscription is the best preserved, and mentions fifteen people, including twelve blacksmiths who are from Hermonthis. The texts also allow kinship ties between certain individuals to be made. This is consistent with what is known of the training of apprentices and the passing on of specialist knowledge associated with certain professions from father to son or within kin groups (Latjar 1991: 63). It is not certain whether all of the craftsmen involved in this ritual and mentioned in the text were from Hermonthis itself, or from all over the Hermonthinite nome. If they were from Hermonthis, it would suggest that a large number of 
blacksmiths were working simultaneously at this city. There is archaeological evidence to suggest that iron working and possibly smelting was taking place at the site (Mond and Myers 1940: 201), although from the description of the slag, it is not possible to say with certainty.

In terms of trying to understand the workings of individual blacksmith's workshops, one of the most important and interesting texts is from the famous Zenon archive, P.Cair.Zen IV 59782(a) 'Account of Iron', dating from somewhere between 261 and 240 B.C. approximately. Although 'pre-Roman', the output of the workshop would be entirely consistent with tools known archaeologically from the Roman Period. The text itself is long but fragmentary, and lists the accounts of a blacksmith's workshop in the months of Pachon, Mesore, Tybi, Phaophi and Payni, although it does not mention a year. A list of tools produced and sharpened, along with the amount of iron used for each task is given. In total, approximately $400 \mathrm{~kg}$ of iron is used to produce thirty different types of metal objects, and to repair and re-edge tools. This is by far the most complete record of any workshop from Egypt and the list of tools is interesting, although it is difficult to provide precise definitions for all of the tools listed. It is also difficult to link these names with specific tool types known from the archaeological record. Even with these problems in mind, it shows that there must have been enough variation between certain items to warrant describing them in accounts as very specific and different things. A list of tools produced by the workshop is as follows:

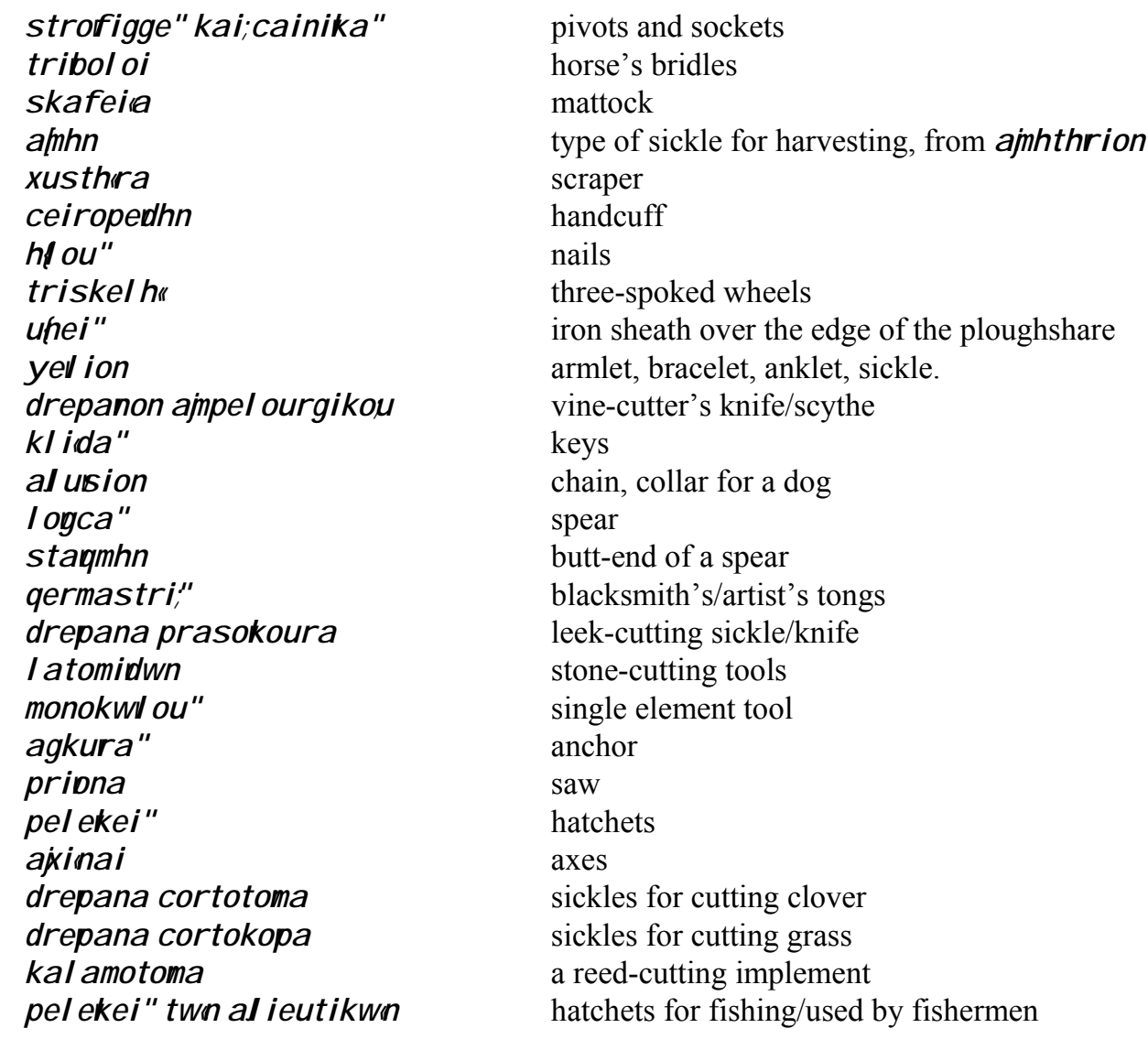




\section{ergalesidhron eijejgal eà}

iron tools

for tools

Apart from this list of terminology for tools, the text also lists a task of the blacksmith hardening (s to mw ma to $\sim$ ) tools. This word is interesting in itself because it can also refer to the scales of iron which fly from hammered iron (l epi $;$ s t o mw ma to $\sim$ ), which are omnipresent on the floors of blacksmith's workshops and are easily detected archaeologically if one is looking for them. As these small pieces of hammer scale are virtually pure iron and high in carbon, it is possible that they could have been collected and made into a flux-like material to aid in adding a hardened edge to a blade. There is no evidence from other texts in relation to this practice, but given the large amount of this type of material that would have been produced by blacksmith's workshops, the practice of collecting and re-using it is certainly a possibility. Smithing experiments by $\operatorname{Sim}$ (1998: 69-70) have shown that up to 40\% of the weight of an iron tool can be lost during the forging and filing of individual objects. This is a considerable amount of waste and any use for by-products of this process would have been desirable.

A noteworthy example of the most common specialist metalworker known from the papyri, the hJ o k o p o (who by literal definition, was a smith who made nails, $h$ K o $u \sim$ ) exists in a group of six texts (Stud.Pal. Vol 8 947, 949, 950, 951 and Stud.Pal. Vol. 20 180, 187). This group of texts, all of which relate to a certain 'Panoubas the nailsmith' ( $\mathrm{P}$ a n o u b a h J ok op w ), might be able to assist in furthering our understanding of the metalworking industry and how it was organised in Egypt. The texts themselves are not dated, although a terminus ante quem of the late second to early third century C.E. can be suggested on the basis of Demotic signatures at the end of the texts. In these texts, various iron items are ordered for use in a public building (dh mo s i o u ), not all of which might be considered the normal produce of a nailsmith if one were to interpret their professional title literally. Of the items that would be standard items for a nailsmith to produce are small nails (h) a r r i w n) (Stud. Pal. Vol. 8947.3 and 951.3), and bars for a door (mo c l i o u $t^{\prime \prime}$ " qura ) (Stud.Pal. Vol. 8 950.2). The most curious item ordered from Panoubas is an iron decoration in the shape of the fruit of the persea (per s e i nou s i dh vou ) (Stud.Pal Vol 8 950.2).

Experimental work by the archaeologist and blacksmith, Sim (1998: 61; Sim and Ridge 2002: 112-115) found that the skills needed to make the shaft/shank of a nail could be taught by a skilled blacksmith to inexperienced people, including children, in a relatively short period of time. The skills needed to add the circular head to the nail proved more difficult to master, but it was the impression of Sim and Ridge (2002: 113) that this is a skill that could still be mastered over time with practice. It is probable that the production of nails would have been at least a two-person job, possibly with a master and apprentice, with the master doing the more complicated task and the apprentice gradually developing skills over time. This would have been achieved by the apprentice making many shanks and operating the bellows for the master, whilst the master added the heads and finished the nails (Sim and Ridge 2002: 113-115). A hypothesis such as this is supported by the nineteenth century account of a wheelwright's workshop (Sturt 1923: 149-150), where the process of nail-making is described as at least a two man job, with one operating the bellows. It is also described as a strenuous and continuous blacksmithing job that 'allowed no intervals for gossip' (Sturt 1923: 149).

Even though some aspects of nail-making are continuous and repetitive, it can be seen quite clearly that the whole process is not an entirely unskilled task. The fact that the Stud.Pal texts suggest that an hJ ok opo (nailsmith) was capable of making more complicated decorative elements such as a decorative fruit design should not be a complete surprise. What is more 
interesting is that this person was not referred to by one of the other more generic terms for a blacksmith, but was rather referred to more specifically as an hJ ok op o (nailsmith). Texts such as these, rather than being seen as providing internally contradictory evidence, should instead be seen as a window on a craft that was obviously more complex in its organisation than one might think. This example, therefore, can be used to highlight the possibility that certain craftspeople may have been able to manufacture objects that one might not expect, and that a broader view of specialisation and identity should be used, rather than simple linear models of hierarchical development of skills.

Other texts illuminate the possible differences between blacksmiths and other specialist smiths such as the nailsmith. P.Oxy 2480, 'Account for the Issue of Wine', relates to specific special events, in this case the distribution of wine, probably for the celebration of Easter, to people who had worked on the estate of the Apion family in A.D. 565-6. In terms of trying to understand how different professional labels related to craft identity, this text is important as it is a very rare example of two metalworking professions being mentioned in the one text. This implies that there was some deliberate choice made by the scribe who chose to identify these people differently. As such, one must assume that this related either to the different tasks that they performed and/or to their status within the hierarchy of the society or workplace in which they lived and worked. Part of the P.Oxy 2480 text mentions 'Macarius the nailsmith' (M a k r i w / h) ok ow (w I), and the 'smiths of the estate' (toi c a I keu ś (i) tw h kthm(a tw n)) as some of the people who received wine for the festival either as a gift or in lieu of salary. It is interesting to note that in this text there is a differentiation between a nailsmith $(\mathrm{h} J \mathrm{ok}$ ow $(\mathrm{w} \mathrm{J})$ and the group of blacksmiths (toi $\sim$ c a l keu s (i)). From this example it is clear that there must have been some distinction in relation to the kind of jobs each of these professionals undertook. One might assume that, as the names implies, a nailsmith simply made nails. However, on the basis of the other group of texts, this does not seem to have been strictly the case. The nailsmith is given wine for his work on the 'plating of the estate's shrimp-shaped boat' (ejga zom(enw) eij ta r I epida th $\sim$ geocik (h $\sim$ ) [ka ]rido ) (P.Oxy 2480.2), whilst the smiths are just acknowledged for 'working here on the great estate shrimp-shaped boat' (ejgazom(enoi ) eij thn ge oci $[k](h n)$ me ga $\mathbf{~ h n ~ k a ~ r i d a ~ ) ~ ( P . O x y ~ 2 4 8 0 . 2 8 ) . ~ T h e ~ t e x t ~ u n f o r t u n a t e l y ~ d o e s ~ n o t ~ p r o v i d e ~ a n y ~}$ more detail, and it is therefore not possible to infer which profession was the most highly regarded, and which was the best rewarded. The smiths receive twice as much wine as the nailsmith, but there are at least twice as many smiths as nailsmiths. If there were three or more smiths, it might be possible to begin to make assumptions based on this one text. However, unless new texts are discovered, this is not possible at present.

These texts show that there was a wide and diverse range of metalworking activities taking place across Egypt in workshops that ranged in size from very large workshops on estates employing several people and producing a large range of specialist tools, to smaller workshops in rural communities with one blacksmith, or military workshops producing tools and weapons at outlying forts and mines. This situation is also reflected in the archaeological evidence that is known to exist, with a variety of workshops extant.

The earliest evidence for iron workshops or production in Egypt comes from the from the seventh century B.C.E. at the sites of Naukratis (Petrie and Gardiner 1886: 39 and Plate XI) and Tell Defenna (Petrie 1888: 79) in the Delta of Egypt. It is uncertain whether smelting or smithing was represented by the evidence at these sites based on the descriptions provided by Petrie. For later periods, the existence of blacksmith's workshops in the archaeological record is equally scant. This could be for a number of reasons that include the concentration of excavations on 
areas of sites where workshops of this type are unlikely to be found, and the relative lack of specialist archaeometallugists working on sites within Egypt as field archaeologists.

The best reported evidence from recent excavations of sites dating to this period is from the Eastern and Western Deserts. The most recently published descriptions of metalworking debris from the Eastern Desert come from the sites of Mons Claudianus (Peacock and Maxfield 1997) and Berenike (Hense 1995; 1996; 1998; 1999; 2000). At Mons Claudianus, the site of imperial granodiorite quarries during the first to third centuries C.E. (Peacock and Maxfield 1997: 333-334), several structures relating to metalworking have been identified and excavated, with some 'Quarry Huts' having been used as blacksmith's workshops for the repair and production of tools used at the quarry (Peacock and Maxfield 1997: 233-237). These huts were chosen specifically for excavation because they had slag associated with them on the surface, and it was anticipated that they would provide information relating to the metallurgical processes at the site (Peacock and Maxfield 1997: 233-234). It is exceptionally rare in Egypt for targeted excavations of Roman Period blacksmith's workshops to be undertaken and to have the results of the analyses of the iron working residues from these huts provided in the same volume, straight after the excavation reports (Freestone 1997: 246-251). The integration of archaeological and analytical results from targeted excavations such as those undertaken at Mons Claudianus is the best way of providing a good contextualised understanding of the place of industry at a site. Excavations at the Red Sea port site of Berenike in the 1994 season yielded bowl-shaped slags, which are normally associated with smithing rather than smelting. The 1998 season also yielded a few fragments of what appear from the descriptions to be 'smithing hearth bottoms' (Hense 2000: 195), further supporting the idea that smithing was taking place on site. As the only published examples of slag from the site seem to be hearth bottoms, and given the distances involved and the relative complexity of smelting as opposed to smithing of iron, it might be more reasonable to suggest that blooms, billets or bars of iron were being imported to Berenike, rather than raw iron ore from Wadi Hammamat.

\section{Case Study: Metalworking at Kellis, Dakhleh Oasis, Egypt}

A study of high-temperature industries in the Dakhleh Oasis of Egypt's Western Desert has recently been completed, part of which involved the excavation of a blacksmith's workshop, analysis of metallurgical debris and slags, and a study of relevant textual material (Eccleston 2006). Material came primarily from the ancient village of Kellis (known today as Ismant el-Kharab), which is located in the centre of the oasis, approximately $15 \mathrm{~km}$ to the east of the capital of Mut and just to the south-east of the modern village of Ismant. The first detailed survey of the entire site was undertaken by the Dakhleh Oasis Project in 1981-2 when it was ascribed the site number 31/420-D6-1. From the 1982-3 season until 1986, some small-scale excavations and survey work was undertaken annually, before large-scale excavations under the direction of Hope began in 1986 (Hope 1988: 160).

Examination of the surface scatters in the north-east corner of the site, known as Area $\mathrm{C} / 2$ revealed the presence of a considerable quantity of metallurgical slag. Over four excavation seasons, namely 1996-1997, 1998-1999, 1999-2000 and 2000-2001, seven test excavations were undertaken at the eastern part of the site on the two low mounds that form this part of the site (Eccleston 2002; Hickson 2002; Hope 1999; 2002). Although it was uncertain exactly what processes produced this debris, preliminary field identification indicated that it was primarily from the working of ferrous rather than non-ferrous metal. Other evidence from the site does 
indicate quite clearly that copper alloys were also being worked at the site (Eccleston 2002). During the study season of 1997-8, a geo-physical survey of Area C/2 of the site was also carried out by Herbic and Smekalova. Their results identified approximately twenty-five magnetic anomalies of varying size and intensity, but possibly consistent with kilns or furnaces (Smekalova 2002). Their results were used in formulating an excavation strategy for the subsequent seasons in $\mathrm{C} / 2$.

Excavations at C/2/6 in 1998-9 revealed the presence of an in situ furnace structure $1.1 \mathrm{~m}$ in diameter and $20 \mathrm{~cm}$ to $25 \mathrm{~cm}$ deep. No superstructure survives, however, based on the internal vitrification of the structure, its shape and the types of slag discovered in association with it there can be no doubt that it was a metalworking furnace (Eccleston 2002; 2006). In January 2000 and January and February 2001, further excavations at C/2/7 were undertaken that incorporated the three largest anomalies identified by the magnetometer (Eccleston 2006; Hope 2003). A structure comprising three rooms was uncovered with one room, Room 1, containing very large quantities of hammer scale embedded on the upper floor levels. Excavation of the floor levels in this room continued using a methodology modified from that of Mills and McDonnell (1992), whereby the floor of the room was divided into twenty-four $50 \mathrm{~cm}$ by $50 \mathrm{~cm}$ grid squares and the matrix from each was kept and the magnetic fraction extracted. By following this excavation methodology, it was possible to show beyond any doubt that a blackmith's workshop was operating in this structure during its occupation in the Early Roman Period (Eccleston 2006). Analysis of slag recovered during excavations in Area $\mathrm{C}$ reveal that they were produced from a smithing rather than a smelting process, which is consistent with the other archaeological evidence from the site (Eccleston 2002; 2006).

The papyrological evidence for metals and metalworking at Kellis is not at all extensive, with various tools and other metal objects known from the papyri (Eccleston 2002). There is only one definite reference to a blacksmith (cal k eu $\forall$ ) from Kellis, along with another two possible references that are based on speculative reconstructions of broken texts. The only clear attestation of a ca I keu $\downarrow$ (bronzesmith or blacksmith) is O.Kell 82 (Worp 2004), and two texts that have an uncertain reading of the word are P.Kell 3 and P.Kell 61 (Worp 1995). O.Kell 82 'Order for a Donkey' was found during excavations undertaken in a rubbish dump (A/10) in January 2000. It is very clear and has been dated by Worp (2004: 20) to the third or fourth century C.E.. The full text reads:

\section{Eijhnof ubaki K eblew \\ parasce ohon \\ tw $/ c$ a l ki onw \\ ta ;ejgalià a ufou' \\ para negki.}

'To the keeper of the peace at Kellis; make a donkey available to the (bronze-)smith in order that it (= the animal) carries his tools' (Worp 2004: 82).

This text is interesting in terms of looking at craft or 'employment' identity as it implies that there was somebody at Kellis who was identified specifically as a bronzesmith or blacksmith (c a I keu $\forall$ ) for the purposes of an official document, and that they were also, in all probability, conducting their profession at smaller villages in the vicinity of Kellis. Based on the archaeological evidence at Kellis and the ambiguous nature of the specific metals the c a I k e u $\forall$ (bronzesmith or blacksmith) worked by this period, it is impossible to say whether they were a 
bronze or an iron smith. The text is also unspecific about where the smith would be taking his tools and donkey. There are several villages known to have existed in the vicinity of Kellis that were smaller in size and status. These sites are identified in the papyri either as $\mathrm{k} w \mathbf{m h}$ (village), ejoikiw/ (hamlet) or cwrion (farm), which relates to their physical size as well as their classification for administrative purposes (Bagnall 1997). Another descriptor associated with toponyms in the papyri, especially prevalent from Hibis in Kharga, is the u r e u (hydreumata), which seems to refer to an outlying area or village of a main city that has access to a well (Wagner 1987: 158-165). There are twenty-one instances of the toponym P mo un J mo u qou occurring in the Kellis Agricultural Account Book, and Bagnall (1997: 75) notes that the toponyms starting with $\mathbf{P}$ mo u $\mathbf{n}$ are probably not villages, but areas of cultivation around a well or natural aquifer that could consist of a small settlement or a few houses.

The organisation of agricultural land in Dakhleh during the Roman Period can be compared to the situation in the oasis today, where a village (beled) can have a smaller settlement (izba) associated with it. The izba is used by the villagers during the harvest so that they can be closer to their outlying fields at this time (Bliss 1998: 34-35). This could be similar to the relationship between a kw mh (village) and a pmoun (well) associated with it. Although the relationship between these sites that can be established purely from the texts is somewhat tenuous, there seems to have been particular sites that were linked closely given the number of references made to them in certain texts. One can imagine a situation during the harvest when crops are being reaped from the area of the pmoun/izba and the need arises to summon the blacksmith from the village to repair or sharpen tools during the harvest. In the Roman Period, as is the case today, the administration of the outlying settlements and the main village are all under the control of a central official; k w ma r c o in the Roman Period (Bagnall 1993: 3), and a sheikh al-beled today (Bliss 1998: 34). If the blacksmith was going to work as part of village business, an eij h n of ul a ki (keeper of the peace) could then have been authorised to sequester a donkey for the use of the blacksmith. This hypothetical scenario gives us some insight into how craftspeople in the village were possibly utilised in certain situations and how the ephemeral details on the ostrakon from Kellis can be placed in a wider social context of village life during the Roman Period.

\section{Conclusions}

This short examination of the metalworking industry in Ptolemaic and Roman Period Egypt gives an insight into the rich body of material that can be utilised in an attempt to understand the organisation of the industry. Based on a detailed examination of the archaeological and textual evidence from Kellis, a more detailed picture of the organisation of industry at the site has begun to emerge. There is clear evidence that iron was being smithed at the site and that copper alloy was also being worked. Textual evidence has also provided a tantalising glimpse into the non-technological aspects of the chaîne opératoire of metalworking at Kellis. Examples of texts and archaeological data from elsewhere in Egypt are now allowing a greater understanding of the organisation of the industry to develop. Not surprisingly, it seems that there were complex relationships between different parts of the industry and that the craft and social identity of the people involved were intertwined with various social, economic and political meanings. Although no definitive solutions can be provided here, there are clearly great benefits to be gained by looking in more detail at the current evidence from texts and other types of material culture. 
Previous scholarship on the pottery and textiles industries, for example, has shown that the organisation of the industry may have been more complex than one might imagine. As a general rule, it is assumed to be the case that high temperature industries were solely the domain of men, whilst 'household' industries such as weaving and basketry were generally the domain of women (Greene 1993: 43-44). This is certainly not true in all cases, as there is a group of textual evidence from Egypt that implies that men were working as weavers at Oxyrhynchus in the first century C.E. (Rowlandson 1998: 112-113). The extant texts imply that it was men that were primarily involved in the high temperature industries in this period, although one should not discount completely the possibility that women were potters or smiths. There is also textual evidence to suggest that women had managerial or controlling interests in workshops in Egypt and elsewhere at this time. This again can be shown by a sixth century C.E. text, P.Cair Masp 67110 , which shows that two women became the owners of a potter's workshop after the death of their father (Rowlandson 1998: 262-263).

In the context of a small rural village in the Egyptian desert, women and children may have been involved, for example, in many aspects of work in a small blacksmith's workshop used by an extended family to make and repair tools and other household implements. It is also possible that women or children were involved in certain aspects of pottery production in the larger workshops at the site. The fact that this occurred would not necessarily be recorded in the types of documents at the site, and is essentially impossible to prove archaeologically. In historical evidence from 'frontier' communities in rural Australia, a domain that is dominated by myths of Australian manhood, there is clear photographic and testimonial evidence that women were involved in a number of trades normally solely associated with men, including blacksmithing (Walker 1978: 63). It is also known that at this time in Australia, women were consciously excluded from official government documents that recorded the number of workers in specific professions and trades (Anderson 1994: 227-228). It is clearly not wise to attempt to draw direct historical analogies between nineteenth-century Australia and Ptolemaic and Roman Egypt. However, the 'common sense' notion that a woman would not be involved in blacksmithing is probably a social construct that can be traced more to a post-Enlightenment notion of middle-class ideals of domesticity, which still continues today in many parts of Western society, rather than a concept that would have existed in Ptolemaic and Roman Egypt.

There is no doubt that the combination of archaeological, textual and analytical data can add a great deal to the study of industry in Ptolemaic and Roman Period Egypt and this is something that I will be pursuing further. When this evidence is then interpreted within current theoretical paradigms used in other areas of archaeology, it is possible to begin to construct ideas about the complex relationships that would have existed within workshops and communities in rural Egypt. When industrial workshops are identified archaeologically, I believe that it is absolutely crucial to adopt a multi-disciplinary approach to their survey and excavation and to the post-excavation study of the materials recovered. This is now happening more frequently at sites across Egypt from a range of different periods and it will become possible to make use of a rich set of data to understand many aspects of Egyptian society. Most importantly I believe that it could be possible to use data from Egyptian workshops and material culture to develop theoretical and interpretative paradigms that other areas of archaeology will want to adopt from Egyptian archaeology, rather than the other way around.

After January 2007: Department of Archaeology, La Trobe University, Melbourne, Australia Department of Archaeology, University of Sheffield 


\section{Bibliography}

Anderson, M. 1994. Good Strong Girls: Colonial Women and Work. In K. Saunders and R. Evans (eds.) Gender Relations in Australia: Domination and Negotiation. Sydney: Harcourt Brace: 225-245.

Andrén, A. 1998. Between Artifacts and Texts: Historical Archaeology in Global Perspective. New York: Plenum Press.

Audouze, F. 2002. Leroi-Gourhan, a Philosopher of Technique and Evolution. Journal of Archaeological Research 10: 277-306.

Bagnall, R.S. 1993. Egypt in Late Antiquity. Princeton: Princeton University Press.

Bagnall, R.S. 1995. Reading Papyri, Writing Ancient History. London: Routledge.

Bagnall, R.S. 1997. The Kellis Agricultural Account Book (P. Kell. IV Gr. 96). Oxford: Oxbow Books.

Bliss, F. 1998. Artisanat et artisanat d'art dans les oasis du désert occidental Égyptien. Köln: Köppe.

Buchez, N. 2004. Les vases à cuire de l'époque prédynastique à Adaïma: aspects, techniques, économiques et culturels. Cahiers de la Céramique Égyptienne 7: 15-45.

Dobres, M.-A. 1999. Technology's Links and Chaînes: The Processual Unfolding of Technique and Technician. In M.-A. Dobres and C. R. Hoffman (eds.) The Social Dynamics of Technology: Practice, Politics, and World Views. Washington DC: Smithsonian Institution Press: 124-146.

Dobres, M.-A. 2000. Technology and Social Agency. Oxford: Blackwell Publishers.

Dobres, M.-A. and Robb, J.E. 2000. Agency in Archaeology. Paradigm or Platitude? In M.-A. Dobres and J.E. Robb (eds.) Agency in Archaeology. London: Routledge: 3-17.

Eccleston, M.A.J. 2002. Metalworking at Kellis: A Preliminary Report. In C.A. Hope and G.E. Bowen (eds.) Preliminary Reports on the 1994-1995 to 1998-1999 Field Seasons. Oxford: Oxbow Books: 143-149.

Eccleston, M.A.J. 2006. Technological and Social Aspects of High-Temperature Industries in the Dakhleh Oasis, Egypt, during the Ptolemaic and Roman Periods. Unpublished Ph.D. thesis, Centre for Archaeology and Ancient History, Monash University.

Edmonds, M. 1990. Description, Understanding and the Chaine Operatoire. Archaeological Review from Cambridge 9: 55-70.

Freestone, I.C. 1997. Iron-Working Residues. In D.P.S. Peacock and V.A. Maxfield (eds.) Mons Claudianus Survey and Excavations 1987-1993. Vol. I. Topography and Quarries. Cairo: Institut Français d'Archéologie Orientale: 246-251.

Greene, K. 1993. The Study of Roman Technology: Some Theoretical Constraints. In E. Scott (ed.) Theoretical Roman Archaeology: First Conference Proceedings. Aldershot: Avebury: 39-47.

Hakim, B.S. 2001. Julian of Ascalon's Treatise of Construction and Design Rules from Sixth-Century Palestine. Journal of the Society of Architectural Historians 60: 4-25.

Hense, A.M. 1995. Metal Finds. In S. Sidebotham and W. Wendrich (eds.) Berenike '94: Preliminary Report of the Excavations at Berenike (Egyptian Red Sea Coast) and the Survey of the Eastern Desert. Leiden: CNWS Publications: 49-57.

Hense, A.M. 1996. Metal Finds. In S. Sidebotham and W. Wendrich (eds.) Berenike '95: Preliminary Report of the Excavations at Berenike (Egyptian Red Sea Coast) and the Survey of the Eastern Desert. Leiden: CNWS Publications: 213-227.

Hense, A.M. 1998. The Metal Finds. In S. Sidebotham and W. Wendrich (eds.) Berenike '96: Preliminary Report of the Excavations at Berenike (Egyptian Red Sea Coast) and the Survey of the Eastern Desert. Leiden: CNWS Publications: 199-220.

Hense, A.M. 1999. The Metal Finds. In S. Sidebotham and W. Wendrich (eds.) Berenike '97: Preliminary Report of the Excavations at Berenike (Egyptian Red Sea Coast) and the Survey of the Eastern Desert. Leiden: CNWS Publications: 219-230.

Hense, A.M. 2000. Metal Finds. In S. Sidebotham and W. Wendrich (eds.) Berenike '98: Report of the 1998 Excavations at Berenike and the Survey of the Eastern Egyptian Desert, including Excavations at Wadi Kalalat. Leiden: CNWS Publications: 191-202. 
Hickey, T.M. and Worp, K.A. 1997. The Dossier of Patermouthios Sidêrourgos. New Texts from Chicago. The Bulletin of the American Society of Papyrologists 34: 79-109.

Hickson, K. 2002. Excavations in Area C at Ismant el-Kharab in 1996-1997. In C.A. Hope and G.E. Bowen (eds.) Dakhleh Oasis Project: Preliminary Reports on the 1994-1995 to 1998-1999 Field Seasons. Oxford: Oxbow Books: 157-166.

Hope, C.A. 1988. Three Seasons of Excavation at Ismant el-Gharab in Dakhleh Oasis, Egypt. Mediterranean Archaeology 1: 160-178.

Hope, C.A.. 1999. The Excavations at Ismant el-Kharab in 1998/9: A Brief Report. The Bulletin of the Australian Centre for Egyptology 10: 59-66.

Hope, C.A. 2002. The Excavations at Ismant el-Kharab in 1994-5 to 1998-9. In C.A. Hope and G.E. Bowen (eds.) Dakhleh Oasis Project: Preliminary Reports on the 1994-1995 to 1998-1999 Field Seasons. Oxford: Oxbow Books: 167-208.

Hope, C.A. 2003. The Excavations at Ismant el-Kharab from 2000 to 2002. In G.E. Bowen and C.A. Hope (eds.) The Oasis Papers 3: Proceedings of the Third International Conference of the Dakhleh Oasis Project. Oxford: Oxbow Books: 207-289.

Johnson, A.C. and van Hoesen, H.B. (eds.) 1931. Papyri in the Princeton University Collections. Volume I. Baltimore: The Johns Hopkins University.

Johnson, J.H. (ed.). 1992. Life in a Multi-Cultural Society: Egypt from Cambyses to Constantine and Beyond. Chicago: The Oriental Institute of the University of Chicago.

Johnson, M.H. 1999. Rethinking Historical Archaeology. In P.P.A. Funari, M. Hall and S. Jones (eds.) Historical Archaeology: Back from the Edge. London: Routledge: 23-36.

Latjar, A. 1991. Proskynema Inscriptions of a Corporation of Iron-workers from Hermonthis in the Temple of Hatshepsut in Deir el-Bahri: New Evidence for Pagan Cults in Egypt in the 4th Century A.D. Journal of Juristic Papyrology 21: 53-70.

Laurence, R. and Berry, J. (eds.). 1998. Cultural Identity in the Roman Empire. London: Routledge.

Lemonnier, P. 1992. Elements for an Anthropology of Technology. Michigan: Museum of Anthropology, University of Michigan.

Leroi-Gourhan, A. 1943. Evolution et techniques: l'homme et la matière. Paris: Albin Michel.

Leroi-Gourhan, A. 1945. Evolution et techniques: milieu et techniques. Paris: Albin Michel.

Leroi-Gourhan, A. 1964a. Le geste et la parole I: technique et langage. Paris: Albin Michel.

Leroi-Gourhan, A. 1964b. Le geste et la parole II: la mémoire et les rythmes. Paris: Albin Michel.

Leroi-Gourhan, A. 1965. Préhistoire de l'art occidental. Paris: Louis Mazenod.

Mattingly, D. 2004. Being Roman: Expressing Identity in a Provincial Setting. Journal of Roman Archaeology 17: 5-25.

Manning, W.H. 1987. Industrial Growth. In J. Wacher (ed.) The Roman World. London: Routledge: 586-610.

Mills, A. and McDonnell, G. 1992. The Identification and Analysis of the Hammerscale from Burton Dassett, Warwickshire. English Heritage, Ancient Monuments Laboratory, Report 47/92.

Mond, R. and Myers, O.H. 1940. Temples of Armant: A Preliminary Survey. London: Egypt Exploration Society.

Moreland, J. 2001. Archaeology and Text. London: Duckworth.

Oates, J., Bagnall, R.S., Clackson, S., O’Brien, A., Sosin, J., Wilfong, T. and Worp, K.A. 2001. Checklist of Editions of Greek and Latin Papyri, Ostraca and Tablets: Fifth Edition. Oakville: American Society of Papyrologists.

Peacock, D.P.S. and Maxfield, V.A. (eds.) 1997. Mons Claudianus Survey and Excavations 1987-1993. Vol. I. Topography and Quarries. Cairo: Institut Français d'Archéologie Orientale.

Petrie, W.M.F. 1888. Tanis, Nebesheh and Defenneh. London: Egypt Exploration Fund.

Petrie, W.M.F. and Gardiner, A. 1886. Naukratis. Part I., 1884-5. London: The Egypt Exploration Fund.

Quaegebeur, J. 1992. Greco-Egyptian Double Names as a Feature of a Bi-cultural Society: The Case Y os neu oJk a i; Tr ia del f o . In J.H. Johnson (ed.) Life in a Multi-Cultural Society: Egypt from 
Cambyses to Constantine and Beyond. Chicago: The Oriental Institute of the University of Chicago: 265-272.

Reil, T. 1913. Beiträge zur Kenntnis des Gewerbes im hellenistischen Ägypten. Leipzig: Borna.

Rowlandson, J. (ed.) 1998. Women and Society in Greek and Roman Egypt: A Sourcebook. Cambridge: Cambridge University Press.

Sim, D. 1998. Beyond the Bloom: Bloom Refining and Iron Artifact Production in the Roman World. Oxford: Archaeopress.

Sim, D. and Ridge, I. 2002. Iron for the Eagles: The Iron Industry of Roman Britain. Stroud: Tempus Publishing.

Smekalova, T.N. 2002. Magnetic Test in Dakhleh Oasis in February 1998 using Overhauser gradiometer GSM-19WG and cesium magnetometer MM-60. In C.A. Hope and G.E. Bowen (eds.) Preliminary Reports on the 1994-1995 to 1997-1998 Field Seasons. Oxford: Oxbow Books: 31-41.

Sturt, G. 1923 [1993]. The Wheelwright's Shop. Cambridge: Cambridge University Press.

Trigger, B.G. 1989. A History of Archaeological Thought. Cambridge: Cambridge University Press.

Wagner, G. 1987. Les Oasis d'Égypte à l'époque grecque, romaine et byzantine d'après les documents grecs (Recherches de papyrologie et d'epigraphie grecques). Cairo: Institut Français d'Archéologie Orientale.

Walker, M. 1978. Pioneer Crafts of Early Australia. Melbourne: Macmillan.

Worp, K.A. 1995. Greek Papyri from Kellis I. Oxford: Oxbow Books.

Worp, K.A. 2004. Greek Ostraka from Kellis. Oxford: Oxbow Books. 